\title{
HUBUNGAN MINAT BELAJAR DENGAN HASIL BELAJAR MATEMATIKA DI MASA PANDEMI COVID-19
}

\author{
Masni $^{1}$, Yonathan S. Pasinggi ${ }^{2}$, Zaid Zainal ${ }^{3}$ \\ 1,2,3 Fakultas Ilmu Pendidikan, Universitas Negeri Makassar \\ e-mail: ${ }^{1}$ masnikamaruddin08@ gmail.com,${ }^{2}$ yonathan.s.pasinggi@unm.ac.id, \\ zzaid@unm.ac.id
}

\begin{abstract}
This research is correlational quantitative research which aims to determine description learning achievement and relationship interest in learning and learning achievement in mathematics during the pandemic of fifth grade primary school students in Cappa Galung Parepare city. The independent variable is interest in learning, the dependent variable is learning achievement. The population were all students of grade V SD in Cappa Galung, Parepare city totaling 70 students, while the sample was 60 students with a sampling technique that is proportional random sampling. The research data were obtained by distributing questionnaires learning interest through google form, learning achievement obtained through teachers. The data analysis technique used linear Product Moment correlation. Descriptive analysis students 'interest in learning and learning achievement showed that students' interest in learning mathematics during the COVID-19 pandemic was in the sufficient category with a mean 57,02, student mathematics learning achievement were in the good category with a mean 67,69. Based on the results of data analysis, the linear correlation coefficient was obtained $\left(r_{x y}\right)=0,603, t_{\text {hitung }}=5,759$, and $p$-value $=0.00$ or HO was rejected, which means that there is a positive relationship interest in learning and student learning achievement with the medium category.
\end{abstract}

Keyword: Learning Interest, Learning Achievement, Mathematics

\begin{abstract}
Abstrak. Penelitian ini adalah penelitian kuantitatif jenis korelasional yang bertujuan untuk mengetahui gambaran hasil belajar serta adanya hubungan antara minat belajar dengan hasil belajar matematika di masa pandemi siswa kelas V SD di kelurahan Cappa Galung kota Parepare. Variabel bebas dalam penelitian ini adalah minat belajar, sedangkan variabel terikat dalam penelitian ini adalah hasil belajar. Populasi dalam penelitian ini adalah seluruh siswa kelas V SD di kelurahan Cappa Galung kota Parepare berjumlah 70 orang, sedangkan sampelnya sebanyak 60 orang dengan teknik pengambilan sampel yaitu proporsional random sampling. Data hasil penelitian diperoleh dengan membagikan angket minat belajar melalui google form, serta hasil belajar yang diperoleh melalui guru kelas. Teknik analisis data yang digunakan yaitu uji korelasi Product Moment. Berdasarkan hasil analisis deskriptif diperoleh minat belajar matematika siswa di masa pandemi COVID-19berada pada kategori cukup dengan nilai rata-rata 57,02, sedangkan hasil belajar matematika siswa berada pada kategori baik dengan nilai ratarata 67,69. Hasil analisis data koefisien korelasi linear diperoleh $\left(r_{x y}\right)=0,603$ dan $t_{\text {hitung }}=5,759$, serta $p$-value $=0,00$ atau $H_{0}$ ditolak, yang berarti bahwa terdapat hubungan yang positif dan signifikan antara minat belajar dengan hasil belajar siswa dengan kategori sedang.
\end{abstract}

Kata Kunci: Minat Belajar, Hasil Belajar, Matematika 


\section{PENDAHULUAN}

Pendidikan memegang peranan yang sangat penting dalam mencerdaskan kehidupan bangsa. Pendidikan yang baik memungkinkan masyarakat dapat mengembangkan potensi dirinya sehingga memiliki akhlak yang mulia dan berguna bagi bangsa dan negara. Sesuai dengan pernyataan bahwa pentingnya pendidikan tersebut, maka didirikan lembaga-lembaga pendidikan di Indonesia, seperti lembaga pendidikan formal, lembaga pendidikan nonformal, dan lembaga pendidikan informal.

Di penghujung tahun 2019, dunia digemparkan adanya pandemi virus corona. Indonesia melaporkan kasus pertama pada 2 Maret 2020, yang menurut dugaan virus tertular dari orang asing yang berkunjung ke Indonesia. Kasus di Indonesia terus bertambah hingga 30 Januari 2021, jumlah kasus infeksi COVID-19 terkonfirmasi mencapai 102 juta kasus dengan total kematian menjadi 2,2 juta jiwa dari 222 negara dan wilayah. Kasus terbanyak terdapat di Amerika yaitu 1.072.287 kasus dengan menurunnya $15 \%$, Brasil 364.593 kasus dengan peningkatan $1 \%$, Inggris Raya dan Irlandia Utara yaitu 178.629 kasus dengan menurunnya $31 \%$, Prancis 141.092 kasus dengan peningkatan 2\%, dan Federasi Rusia dengan kasus 131.039 dengan menurunnya $13 \%$. Di Indonesia, jumlah kasus sebanyak 1.066.313, dengan total kematian sebanyak 29.728 kasus (World Health Organization, 2020).

Salah satu wilayah yang terdampak COVID-19 adalah Kota Parepare. Kota Parepare merupakan salah satu wilayah di
Provinsi Sulawesi Selatan. Kota Parepare memiliki empat Kecamatan yaitu Kecamatan Soreang, Kecamatan Bacukiki, Kecamatan Ujung, dan Kecamatan Bacukiki Barat (Peraturan Walikota Parepare, 2011). Kecamatan Bacukiki Barat terbagi menjadi enam kelurahan yaitu Kelurahan Lumpue, Kelurahan Sumpang Minangae, Kelurahan Cappa Galung, Kelurahan Tiro Sompe, Kelurahan Kampung Baru, dan Kelurahan Bumi Harapan. Adapun di Kelurahan Cappa Galung terdapat lima Sekolah Dasar, yaitu SD Negeri 16 Parepare, SD Negeri 45 Parepare, SD Negeri 57 Parepare, SD Negeri 66 Parepare, dan SD Negeri 80 Parepare (BPS Kota Parepare, 2019).

Matematika adalah salah satu mata pelajaran yang diajarkan di jenjang sekolah dasar dengan pengenalan konsep yang utuh. Pasinggi \& Zainal (2018) menjelaskan bahwa matematika merupakan ilmu dasar yang menjadi alat untuk mempelajari ilmu-ilmu yang lain. Konsep dalam matematika merupakan rangkaian sebab-akibat yang disusun sesuai konsep-konsep sebelumnya dan menjadi dasar bagi konsep selanjutnya, sehingga pemahaman siswa harus dimulai dari pemahaman konsep awal.

Penelitian terkait minat belajar siswa yang memiliki hubungan dengan hasil belajar siswa yaitu penelitian (Alwina, Syahrilfuddin, \& Fendrik, 2016) menunjukkan hasil penelitian dengan nilai korelasi sebesar 0,374 dengan tingkat hubungan yang rendah. Uji $t$ diperoleh thitung sebesar 3,722 dan diperoleh $t_{\text {tabel }}$ sebesar 1,663. Hal tersebut berarti bahwa terdapat hubungan yang signifikan antara 
minat belajar dengan hasil belajar matematika siswa kelas V SDN Gugus 4 Kecamatan Lima Puluh Kota Pekanbaru.

Suciyati \& Mariamah (2018) dalam penelitiannya menunjukkan bahwa minat belajar dan hasil belajar matematika memiliki hubungan yang berada pada kategori sedang. Berdasarkan hasil penghitungan uji hipotesis minat belajar terhadap hasil belajar matematika siswa kelas V SD Negeri 4 Sila menunjukkan nilai $r$ hitung $(0,584)>r$ tabel $(0,361)$ dan nilai $\mathrm{t}$ hitung $(3,019)>\mathrm{t}$ tabel (1,734), maka $\mathrm{H}_{1}$ diterima dan $\mathrm{H}_{0}$ ditolak, yang artinya bahwa terdapat hubungan antara minat belajar dengan hasil belajar matematika siswa kelas V SD Negeri 4 Sila.

Berdasarkan beberapa penelitian terdahulu yang menunjukkan bahwa terdapat hubungan antara minat belajar dengan hasil belajar, maka penelitian ini perlu dilakukan untuk mengetahui hubungan antara minat belajar dengan hasil belajar siswa di masa pandemi COVID-19 terutama pada mata pelajaran matematika yang subjeknya berada pada sekolah yang berbeda dalam satu kelurahan. Hal tersebut didasari bahwa proses penyampaian materi dari berbagai sumber pendidik (guru) berpengaruh pada penerimaan pesan atau pemahaman yang diperoleh siswa, sehingga minat belajar siswa juga akan beragam sesuai dengan metode mengajar guru. Penelitian ini dilakukan sebagai bahan evaluasi pihak terkait dengan pendidikan atau orang tua agar dapat lebih memahami pentingnya perwujudan serta partisipasi dalam mendampingi siswa belajar agar siswa lebih antusias meningkatkan minatnya dalam mengikuti pembelajaran daring. Hal ini sangat penting karena minat belajar memiliki hubungan dengan hasil belajar siswa. Jika tidak segera dibenahi kekurangannya, maka akan berakibat fatal pada hasil belajar siswa terlebih lagi di masa pandemi COVID-19.

Syahputra (2020) menyatakan bahwa minat belajar adalah aspek psikologis seseorang yang menampakkan diri dalam beberapa gejala meliputi adanya gairah, keinginan, semangat, dan perasaan suka untuk melakukan perubahan tingkah laku dari berbagai kegiatan mencari pengetahuan dan pengalaman. Minat belajar adalah perhatian, rasa suka, ketertarikan seseorang terhadap proses belajar yang dijalaninya dan akan ditunjukkan melalui keantusiasan, partisipasi, dan keaktifan dalam mengikuti proses belajar yang ada.

Siswa yang memiliki minat terhadap matematika akan cenderung memberikan perhatian lebih terhadap objek terkait dengan matematika tersebut. (Tiurma \& Retnawati, 2014) menyatakan bahwa siswa yang memiliki minat terhadap objek tertentu akan cenderung untuk memberikan perhatian lebih besar terhadap objek tersebut. Materi matematika, pembelajaran matematika, guru matematika, buku matematika, tugas matematika, dan ulangan matematika merupakan objek minat terhadap matematika. Siswa yang memiliki minat belajar matematika akan memiliki perhatian yang besar terhadap objek matematika. 
Halik, Sultan, \& Zainal, (2017) menyatakan bahwa keberhasilan belajar seorang siswa akan sangat ditentukan oleh kemampuannya memahami sebuah informasi. Hal ini juga berlaku pada pembelajaran matematika, hasil belajar matematika siswa ditentukan oleh kemampuannya memahami informasi dan menganalisis suatu masalah untuk menemukan solusinya.

\section{METODE}

Penelitian ini menggunakan metode kuantitatif dengan jenis penelitiannya korelasional. Sugiyono (2019) yang mengemukakan metode penelitian kuantitatif digunakan untuk meneliti pada populasi dan sampel, pengumpulan data dengan instrumen penelitian, analisis data statistik, dengan tujuan untuk menguji hipotesis yang telah diterapkan. Sementara penelitian korelasional adalah penelitian untuk mengetahui tingkat hubungan dua variabel atau lebih, tanpa melakukan perubahan, tambahan, atau manipulasi terhadap data yang ada (Duli, 2019). Untuk mengetahui tingkat hubungan antar variabel tersebut dibutuhkan alat/instrumen yang digunakan yaitu angket minat belajar matematika dan dokumentasi hasil belajar matematika semester ganjil. Penelitian ini dilakukan di empat sekolah yang berada di kelurahan Cappa Galung kota Parepare, yaitu UPTD SD Negeri 45 Parepare, UPTD SD Negeri 57 Pareparte, UPTD SD Negeri 66 Parepare, dan UPTD SD Negeri 80 Parepare. Cara penentuan sampel yaitu dengan teknik proporsional random sampling dengan menggunakan persamaan Slovin.

Penghitungan sampel penelitian menggunakan formula empiris yang dianjurkan oleh Slovin (1960) dapat dituliskan dalam persamaan sebagai berikut:

$$
\mathrm{n}=\frac{\mathrm{N}}{1+\mathrm{N} \cdot \mathrm{e}^{2}}
$$

\section{Keterangan :}

$\mathrm{N}=$ Total populasi

$\mathrm{n}=$ Jumlah sampel

$\mathrm{e}=\alpha=0,05 / 0,1$ adalah besarnya penyimpangan,

ketelitian, atau kecermatan (Riyanto \&

Hatmawan, 2020, h. 12).

Jumlah siswa kelas V SD Negeri di Kelurahan Cappa Galung sebanyak 70 siswa, maka berdasarkan rumus di atas, perhitungan sampel yang diambil adalah sebagai berikut :

$$
\begin{aligned}
& \mathrm{n}=\frac{\mathrm{N}}{1+\mathrm{N} \cdot \mathrm{e}^{2}} \\
& \mathrm{n}=\frac{70}{1+\left(70 \times 0,05^{2}\right)} \\
& \mathrm{n}=\frac{70}{1,175} \\
& n=59,57 \\
& n=60
\end{aligned}
$$

\begin{tabular}{|c|c|c|}
\hline No. & Nama Sekolah & Jumlah Sampel \\
\hline 1. & $\begin{array}{c}\text { UPTD SD Negeri } 45 \\
\text { Parepare }\end{array}$ & $\begin{array}{c}(28 \times 60): 70=24 \\
\text { Siswa }\end{array}$ \\
\hline 2. & $\begin{array}{c}\text { UPTD SD Negeri } 57 \\
\text { Parepare }\end{array}$ & $\begin{array}{c}(14 \times 60): 70=12 \\
\text { Siswa }\end{array}$ \\
\hline 3. & $\begin{array}{c}\text { UPTD SD Negeri } 66 \\
\text { Parepare }\end{array}$ & $\begin{array}{c}(16 \times 60): 70=14 \\
\text { Siswa }\end{array}$ \\
\hline 4. & $\begin{array}{c}\text { UPTD SD Negeri } 80 \\
\text { Parepare } \\
\text { Total sampel }\end{array}$ & $\begin{array}{c}(12 \times 60): 70=10 \\
\text { Siswa } \\
60 \text { siswa }\end{array}$ \\
\hline
\end{tabular}

Tabel 1. Sampel Kelas V Setiap Sekolah 
Tabel 2. Kisi-Kisi Minat Belajar Matematika

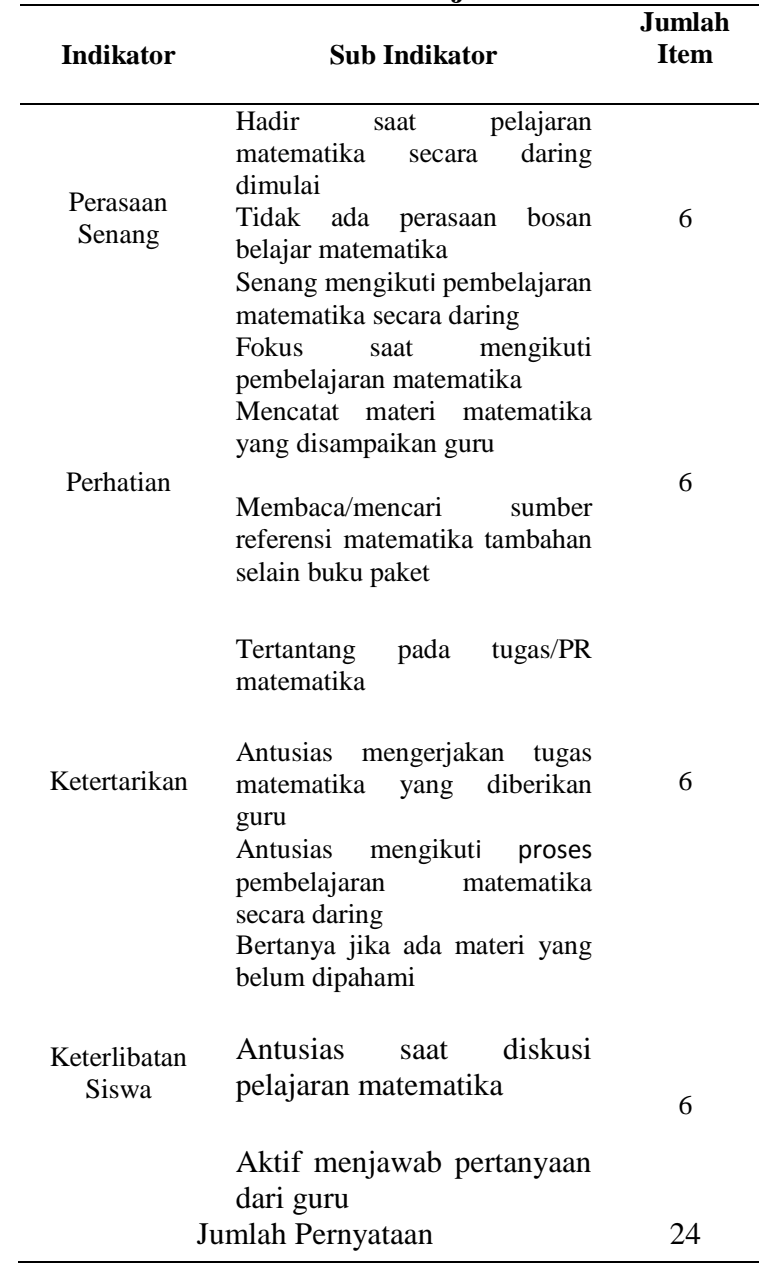

Sumber: Syahputra (2020)

Berdasarkan kisi-kisi, dapat disusun instrumen penelitiannya. Instrumen yang digunakan dalam penelitian ini adalah angket dengan skala likert. Adapun pedoman penskoran dalam instrumen penelitian ini adalah sebagai berikut.

Tabel 3. Skor Alternatif Jawaban Angket Minat

\begin{tabular}{ccc} 
Belajar & \multicolumn{2}{c}{ Skor Pernyataan } \\
\hline Alternatif & Positif & Negatif \\
Jawaban & 4 & 1 \\
Selalu & 3 & 2 \\
Sering & 2 & 3 \\
Kadang-kadang & 1 & 4 \\
Tidak pernah & 1 &
\end{tabular}

Sumber: (Riyanto et al., 2020)

\section{HASIL DAN PEMBAHASAN}

Data yang diperoleh dari lokasi penelitian yang meliputi data minat belajar matematika siswa serta data hasil belajar matematika siswa selanjutnya akan disajikan dalam bentuk tabel untuk memudahkan penafsiran data. Data variabel penelitian minat belajar (X) dan hasil belajar matematika (Y) tersebut dapat disajikan sebagai berikut.

Tabel 4. Statistik Deskriptif Data Minat Belajar dan Hasil Belajar Matematika

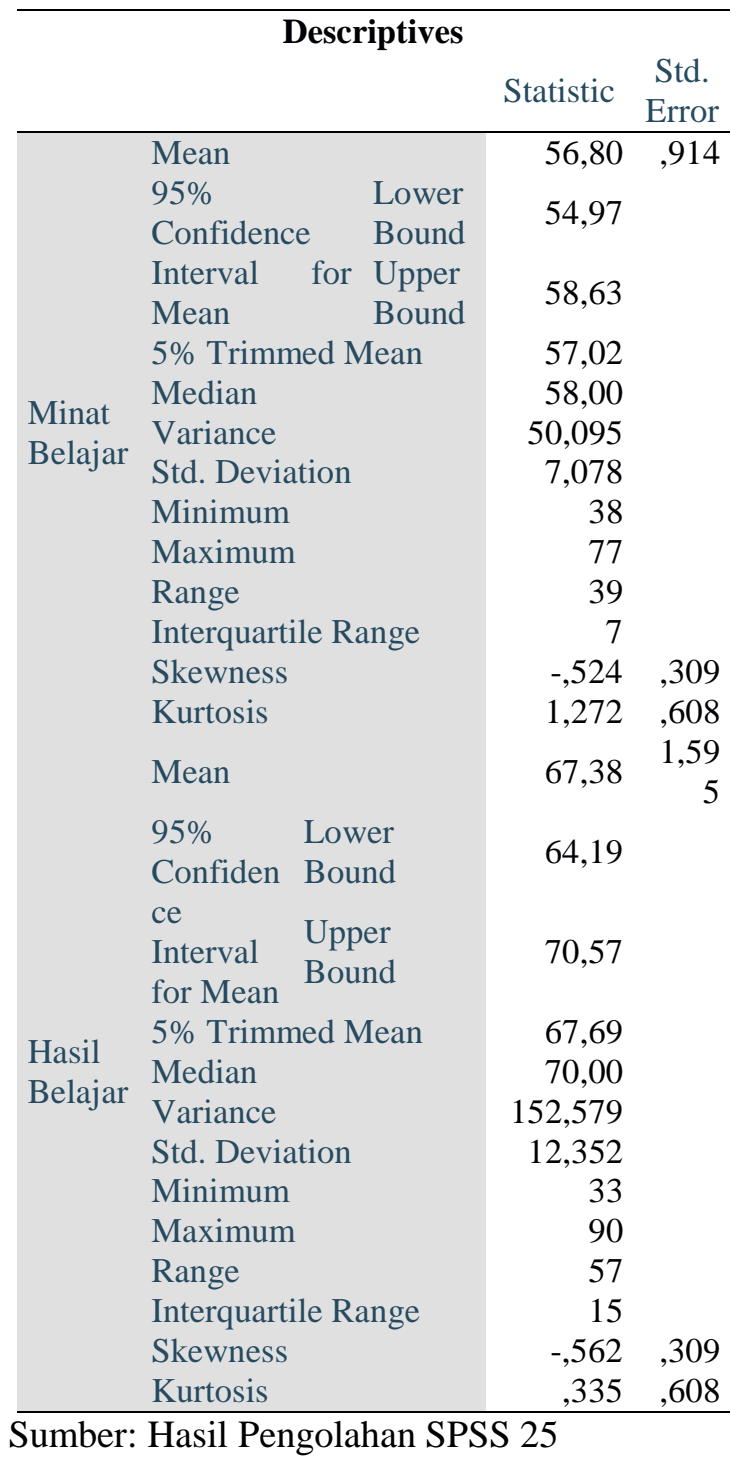


Tabel 5. Hasil Angket Minat Belajar

\begin{tabular}{ccccc}
\multicolumn{5}{c}{ Matematika } \\
\hline No & Interval & Kriteria & Frekuensi & Persentase \\
\hline 1 & $24-41$ & Kurang & 3 & 5 \\
2 & $42-59$ & Cukup & 37 & 61,7 \\
3 & $60-77$ & Baik & 20 & 33,3 \\
& \multicolumn{5}{c}{ Sangat } & 0 & 0 \\
4 & $78-96$ & Baik & $\mathbf{6 0}$ & $\mathbf{1 0 0}$ \\
\hline \multicolumn{7}{c}{ Jumlah } & &
\end{tabular}

Sumber: Setiyabudi \& Purnami (2015)

Berdasarkan data yang disajikan pada tabel minat belajar matematika menunjukkan dari 60 siswa, terdapat 3 siswa yang tergolong memiliki minat belajar yang kurang dengan persentase 5\%, 37 siswa yang tergolong memiliki minat belajar yang cukup, dengan persentase $61,7 \%$, dan 20 siswa yang tergolong memiliki minat belajar yang baik, dengan persentase 33,3\%. Hasil dari perhitungan rata-rata minat belajar siswa menggunakan SPSS 25 adalah 57,02. Hal tersebut berarti bahwa minat belajar matematika di masa pandemi COVID-19 siswa kelas V SD di kelurahan Cappa Galung kota Parepare termasuk kategori cukup.

Tabel 6. Hasil Belajar Matematika Siswa

\begin{tabular}{|c|c|c|c|}
\hline No. & Interval & Kriteria & Frekuensi \\
\hline 1. & $81-100$ & Sangat Baik & 5 \\
\hline 2. & $61-80$ & Baik & 37 \\
\hline 3. & $41-60$ & Sedang & 16 \\
\hline 4. & $21-40$ & Buruk & 2 \\
\hline 5. & $0-20$ & Buruk Sekali & 0 \\
\hline \multicolumn{3}{|c|}{ Jumlah } & 60 \\
\hline
\end{tabular}

Sumber: Sofnidar \& Yuliana, (2018)

Berdasarkan data yang disajikan pada tabel hasil belajar matematika, dari 60 siswa sebagai sampel penelitian, hanya terdapat 2 siswa yang memiliki hasil belajar yang buruk, 16 siswa memiliki hasil belajar sedang, 37 siswa memiliki hasil belajar baik, dan 5 siswa memiliki hasil belajar sangat baik. Hasil dari perhitungan rata-rata hasil belajar siswa menggunakan SPSS 25 adalah 67,69. Hal tersebut berarti bahwa hasil belajar matematika siswa kelas V SD di Kelurahan Cappa Galung kota Parepare tergolong baik selama proses pembelajaran daring.

Sebelum dilakukan uji hipotesis, terlebih dahulu data penelitian harus dilakukan uji normalitas. Uji normalitas dilakukan menggunakan SPSS versi 25 dengan hasil uji sebagai berikut:

Tabel 7. Uji Normalitas dengan SPSS 25

\begin{tabular}{lrrr}
\hline & \multicolumn{3}{c}{ Kolmogorov-Smirnov } \\
& Statistic & df & Sig. \\
\cline { 2 - 4 } Minat Belajar &, 138 & 60 &, 006 \\
Hasil Belajar &, 134 & 60 &, 009 \\
\hline
\end{tabular}

Sumber: Hasil Pengolahan SPSS 25

Nilai Sig > 0,05 menunjukkan bahwa data berdistribusi normal. Data hasil penelitian dari variabel minat belajar dan hasil belajar yang telah berdistribusi normal, maka dapat dilakukan uji hipotesis.

Uji korelasi product moment:

$$
\begin{aligned}
& r_{x y}=\frac{N \sum x y-\left(\sum X\right)\left(\sum Y\right)}{\sqrt{\left[N \sum X^{2}-(X)^{2}\right]\left[N \sum Y^{2}-(Y)^{2}\right]}} \\
& r_{x y}=\frac{60 \times 232.751-(3408)(4043)}{\sqrt{\left[60 \times 196530-(3408)^{2}\right]\left[60 \times 281433-(4043)^{2}\right]}} \\
& r_{x y}=\frac{13965060-13778544}{\sqrt{[11791800-11614464][16885980-16345849]}} \\
& r_{x y}=\frac{186516}{\sqrt{[177336][540131]}} \\
& r_{x y}=\frac{186516}{309491} \\
& r_{x y}=0,602654 \\
& r_{x y}=0,603
\end{aligned}
$$

Jadi, koefisien korelasi minat belajar dan hasil belajar matematika adalah 0,603.

Untuk menentukan koefisien korelasi data penelitian dapat juga menggunakan SPSS versi 25 sebagai berikut: 
Tabel 8. Uji Korelasi dengan SPSS 25

\begin{tabular}{llrr}
\hline \multicolumn{3}{c}{ Correlations } \\
& & $\begin{array}{c}\text { Minat } \\
\text { Belajar }\end{array}$ & $\begin{array}{c}\text { Hasil } \\
\text { Belajar }\end{array}$ \\
\hline Minat & Pearson Correlation & 1 &, $603^{* *}$ \\
Belajar & Sig. (2-tailed) & &, 000 \\
& N & 60 & 60 \\
Hasil & Pearson Correlation &, $603^{* *}$ & 1 \\
Belajar & Sig. (2-tailed) &, 000 & 60 \\
& N & 60 & 60 \\
\hline
\end{tabular}

Sumber: Hasil Pengolahan SPSS 25

Dari tabel tersebut diperoleh nilai korelasi $r_{x y}=0,603$. Adapun pedoman untuk memberikan interpretasi kekuatan hubungan koefisien korelasi dapat diamati dari tabel berikut:

\begin{tabular}{|c|c|}
\hline Nilai $\mathbf{r}$ & Interpretasi \\
\hline 0,900 s.d. 1,000 (-0,900 s.d. & Korelasi (+/-) \\
\hline$-1,000)$ & Sangat Tinggi \\
\hline 0,700 s.d. 0,900 (-0,700 s.d. & Korelasi $(+/-)$ \\
\hline$-0,900)$ & Tinggi \\
\hline $\begin{array}{c}0,500 \text { s.d. } 0,700(-0,500 \text { s.d. } \\
-0,700)\end{array}$ & $\begin{array}{l}\text { Korelasi }(+/-) \\
\quad \text { Sedang }\end{array}$ \\
\hline $\begin{array}{c}0,300 \text { s.d. } 0,500(-0,300 \text { s.d. } \\
-0,500)\end{array}$ & $\begin{array}{l}\text { Korelasi (+/-) } \\
\text { Rendah }\end{array}$ \\
\hline 0,000 s.d. $0,300(-0,000$ s.d. & $\begin{array}{l}\text { Korelasi (+/-) } \\
\text { Tidak Berarti }\end{array}$ \\
\hline
\end{tabular}

Sumber: (Hanief \& Himawanto, 2017)

Uji signifikansi dilakukan sebelum menginterpretasikan data perhitungan uji korelasi Product Moment. Hal ini dilakukan untuk mengetahui apakah terdapat hubungan antara variabel bebas dan variabel terikat dari data penelitian.

Hipotesis uji:

$\mathrm{H}_{0}: \rho=0$ (Tidak terdapat hubungan yang signifikan antara minat belajar dengan hasil belajar matematika siswa di masa pandemi COVID19).

$\mathrm{H}_{0:} \rho \neq 0 \quad$ (Terdapat hubungan yang signifikan antara minat belajar dengan hasil belajar matematika siswa di masa pandemi COVID-19).

$$
\begin{aligned}
& \mathrm{t}_{\text {hitung }}=\frac{r x y \sqrt{n-2}}{\sqrt{1-r_{x y}^{2}}} \\
& \mathrm{t}_{\text {hitung }}=\frac{0,603 \sqrt{60-2}}{\sqrt{1-0,603^{2}}} \\
& \mathrm{t}_{\text {hitung }}=\frac{0,603 \sqrt{58}}{\sqrt{1-0,3636}} \\
& \mathrm{t}_{\text {hitung }}=\frac{0,603 \times 7,61}{\sqrt{1-0,3636}} \\
& \mathrm{t}_{\text {hitung }}=\frac{4,59}{\sqrt{0,6364}} \\
& \mathrm{t}_{\text {hitung }}=\frac{4,59}{0,797} \\
& \mathrm{t}_{\text {hitung }}=5,759
\end{aligned}
$$

Kriteria uji dengan $\alpha=0,05$ dan $n=60$ maka dapat ditentukan nilai $t_{\text {tabel. }}$ Nilai $t_{\text {tabel }}$ dapat dicari dengan melihat titik perpotongan antara taraf signifikansi atau probability dengan degree of freedom (df).

Langkah pertama yang dilakukan dalam menentukan nilai $t_{\text {tabel }}$ adalah mencari angka degree of freedom (df) menggunakan rumus berikut:

$$
\begin{aligned}
& \mathrm{df}=\mathrm{n}-\mathrm{k} \\
& \mathrm{df}=60-2 \\
& \mathrm{df}=58
\end{aligned}
$$

Taraf signifikansi disesuaikan dengan hipotesis penelitian. Untuk hipotesis penelitian dengan tujuan mengetahui apakah terdapat hubungan antara dua variabel tanpa diketahui hubungan positif atau negatif, maka taraf signifikansi yang digunakan adalah 0,025 untuk uji dua arah. Jika nilai probability dan degree of freedom telah diketahui, selanjutnya membaca tabel t. Hasil dari perpotongan nilai dari probability $(0,025)$ dan degree of freedom (58) menunjukkan angka 2,00172 sehingga $\mathrm{H}_{0}$ ditolak jika $\mathrm{t}>2,00172$ atau $\mathrm{t}<-2,00172$. 


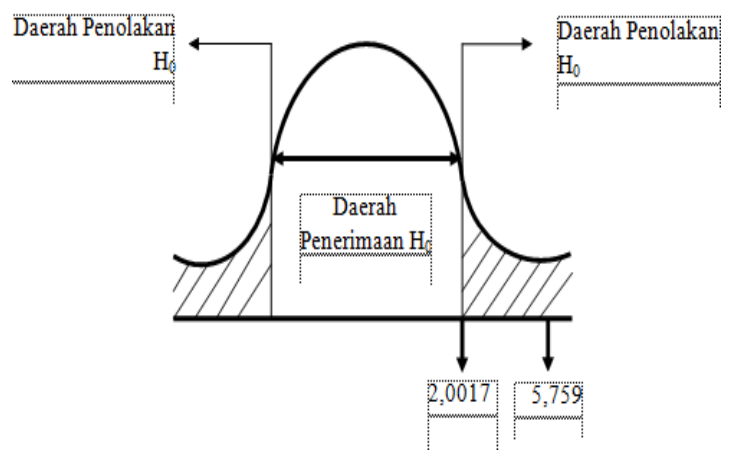

Gambar 1. Kurva Uji Signifikansi Data Penelitian

\section{Pembahasan}

Analisis deskriptif minat belajar dan hasil belajar siswa diperoleh minat belajar matematika siswa di masa pandemi COVID19 dari 60 siswa, terdapat 3 siswa yang tergolong memiliki minat belajar yang kurang dengan persentase 5\%, 37 siswa yang tergolong memiliki minat belajar yang cukup, dengan persentase $61,7 \%$, dan 20 siswa yang tergolong memiliki minat belajar yang baik, dengan persentase $33,3 \%$. kategori cukup dengan persentase $61,7 \%$. Adapun hasil dari perhitungan rata-rata minat belajar siswa menggunakan SPSS 25 adalah 57,02. Hal tersebut berarti minat belajar siswa berada pada kategori cukup.

Hasil belajar matematika siswa dari 60 siswa sebagai sampel penelitian, hanya terdapat 2 siswa yang memiliki hasil belajar yang buruk, 16 siswa memiliki hasil belajar sedang, 37 siswa memiliki hasil belajar baik, dan 5 siswa memiliki hasil belajar sangat baik. Hasil dari perhitungan rata-rata hasil belajar siswa menggunakan SPSS 25 adalah 67,69. Hal tersebut berarti bahwa hasil belajar matematika siswa kelas V SD di Kelurahan Cappa Galung kota Parepare tergolong baik.
Analisis data dengan korelasi Product Moment diperoleh $\left(\mathrm{r}_{\mathrm{xy}}\right)=0,603$ dan $\mathrm{t}_{\text {hitung }}=$ 5,759, serta $\mathrm{p}$-value $=0,00<0,05$ atau $\mathrm{H}_{0}$ ditolak. Dengan demikian, interpretasi koefisien korelasi $\mathrm{X}$ dan $\mathrm{Y}$ adalah terdapat hubungan yang positif dan signifikan antara minat belajar dengan hasil belajar matematika dengan kategori sedang. Hal ini menunjukkan bahwa semakin tinggi minat belajar matematika siswa, maka akan semakin tinggi pula hasil belajar matematika yang diperolehnya. Perubahan minat belajar memiliki hubungan secara langsung dengan hasil belajar. Hasil penelitian ini sejalan dengan pendapat Dalyono (2009) yang menjelaskan bahwa minat belajar siswa yang besar cenderung akan menghasilkan hasil belajar yang tinggi, dan sebaliknya jika minat belajar yang kurang, maka akan menghasilkan hasil belajar yang rendah (Syahputra, 2020).

Minat belajar memiliki hubungan dengan hasil belajar matematika siswa dengan nilai korelasi 0,603 dengan kategori hubungan sedang. Adanya hubungan antara variabel minat belajar dengan hasil belajar matematika dijelaskan dalam penelitian (Suciyati et al., 2018) yang menunjukkan bahwa minat belajar dan hasil belajar matematika memiliki hubungan yang berada pada kategori sedang. Berdasarkan hasil penghitungan uji hipotesis minat belajar terhadap hasil belajar matematika siswa kelas V SD Negeri 4 Sila menunjukkan nilai $r$ hitung $(0,584)>r$ tabel $(0,361)$ dan nilai $t$ hitung $(3,019)>\mathrm{t}$ tabel $(1,734)$, maka $\mathrm{H}_{1}$ diterima dan $\mathrm{H}_{0}$ ditolak, yang artinya bahwa 
terdapat hubungan antara minat belajar dengan hasil belajar matematika siswa kelas V SD Negeri 4 Sila.

\section{SIMPULAN}

Berdasarkan rumusan masalah melalui pengolahan data dan pembahasan, maka dapat disimpulkan bahwa terdapat hubungan yang positif dan signifikan antara minat belajar dengan hasil belajar matematika pada kategori hubungan sedang.

Minat belajar siswa perlu ditingkatkan dengan adanya peran serta kerjasama berbagai elemen pendidikan dan orang tua dalam rangka menyediakan fasilitas dan sarana belajar yang mendukung proses belajar siswa sehingga siswa memperoleh pengalaman belajar yang menyenangkan serta hasil belajarnya juga dapat meningkat.

\section{UCAPAN TERIMA KASIH}

1. Hj. Nahriah, S.Pd., M.Pd. sebagai Plt Kepala UPTD SD Negeri 45 Parepare; Evi Sirajuddin, S.Pd., M.M sebagai Plt Kepala UPTD SD Negeri 66 Parepare; Jamilah, S.Pd.SD sebagai Plt Kepala UPTD SD Negeri 57 Parepare; dan Halpiah, S.Pd.SD sebagai Plt Kepala UPTD SD Negeri 80 Parepare

2. Wali kelas V SD di Kelurahan Cappa Galung Kota Parepare

3. Teristimewa kepada kedua orang tua tercinta, Kamaruddin (Alm.) dan Ode Nurhaeda serta segenap keluarga besar yang senantiasa memberikan doa, dukungan, bantuan berupa moril maupun materi.

\section{DAFTAR PUSTAKA}

Alwina, A., Syahrilfuddin., \& Fendrik, M. 2016. Hubungan Minat Belajar dengan Hasil Belajar Matemaika Siswa Kelas V Gugus 4 Kecamatan Lima Puluh Kota Pekanbaru. Jurnal Online Mahasiswa Fakultas Keguruan dan Ilmu Pendidikan,3(2),1-12.Diakses 27 Januari 2021 dari https://jom.unri.ac.id/index.php/JOMFKI P/article/view/12011.

BPS Kota Parepare. 2019. Kecamatan Bacukiki Barat dalam Angka. Parepare: CV Cipta Buana Lestari.

Duli, N. 2019. Metode Penelitian Kuantitatif: Beberapa Konsep Dasar untuk Penulisan Skripsi \& Analisis Data dengan SPSS.Yogyakarta: Deepublish.

Halik, A., Sultan, M. A., \& Zainal, Z. 2017. Efektifitas Pembelajaran Cooperative Scrift dalam Meningkatkan Kemampuan Memahami Bacaan Siswa Kelas V SD Negeri 17 Parepare. Jurnal Publikasi Pendidikan, 7(3), 173-183.

Hanief, Y.N., \& Himawanto, W. 2017. Statistik Pendidikan. Yogyakarta: Deepublish.

Pasinggi, Y. S., \& Zainal, Z. 2018. Pendidikan Matematika 1: Bilangan, Faktor, dan Kelipatan Persekutuan. Makassar: Badan Penerbit Universitas Negeri Makassar.

Peraturan Walikota Parepare Nomor 10 Tahun 2011 tentang Rencana Tata Ruang Wilayah Kota Parepare Tahun 20112031.

Riyanto, S., \& Hatmawan, A. A. 2020. Metode Riset Penelitian Kuantitatif Penelitian di Bidang Manajemen, Teknik, Pendidikan, dan Eksperimen. Yogyakarta: Deepublish. 
Setiyabudi \& Purnami, A. S. 2015. Peningkatan Minat dan Prestasi Belajar Matematika Siswa melalui Model Pembelajaran Mastery Learning. Jurnal Ilmiah Pendidikan Matematika, 3(3), 337-344.

Suciyati, \& Mariamah. 2018. Hubungan antara Minat Belajar dengan Hasil Belajar Matematika pada Siswa Kelas V SD Negeri 04 Sila. Jurnal Pendidikan Mipa, 8(2),142-149. https://doi.org/10.37630/jpm.v8i2.265.

Sofnidar, \& Yuliana, R. 2018. Pengembangan Media melalui Aplikasi Adobe Flash dan Photoshop Berbasis Pendekatan Saintifik. Jurnal Gentala Pendidikan Dasar, 3(2), 257-275.

Syahputra, E. 2020. Snowball Throwing Tingkatkan Minat dan Hasil Belajar. Sukabumi: Haura Publishing. 